\title{
Hak dan Kewajiban Guru dan Siswa dalam QS Luqman Ayat 13-19
}

\author{
Alex Nanang Agus Sifa \\ Institut Agama Islam Negeri Purwokerto \\ alexnanangas@gmail.com
}

Naskah diterima: 30 Maret 2020| Naskah disetujui: 21 April 2020

\begin{abstract}
In the concept of Islamic education, Qur'an is the main source that guides the ongoing education process. It contains principles that are closely related to educational values, including the education of parents to their children as contained in the surah Luqman verses 13-19. This article seeks to uncover patterns of relationships between parents and children which are interpreted through the relationship between teacher and student in terms of their rights and obligations. The method used in this research is content analysis combined with the thematic interpretation method (maudhu'i). This study concludes that teacher and student have rights and obligations that are complementary and constitute a unity. That is, the rights of a student are the obligations of a teacher and the obligations of a student are the rights of a teacher. Both teacher and student have the same rights and obligations in order to obey the commands of Allah SWT.
\end{abstract}

Keywords: Rights and obligations, teacher, student, Surah Luqman verses 13-19

\begin{abstract}
Abstrak
Dalam konsep pendidikan Islam, Al-Qur'an merupakan sumber utama yang menjadi pedoman berlangsungnya proses pendidikan. Di dalamnya terkandung prinsip-prinsip yang terkait erat dengan nilai-nilai pendidikan, diantaranya adalah tentang pendidikan yang dilakukan oleh orang tua kepada anaknya sebagaimana yang terdapat dalam surat Luqman ayat 13-19. Artikel ini berusaha mengungkap pola hubungan antara orang tua dan anak tersebut yang diinterpretasikan melalui hubungan antara guru dan siswa dalam hal hak dan kewajiban keduanya. Adapun metode yang digunakan dalam penelitian ini adalah analisis isi (content analysis) yang dipadukan dengan metode tafsir tematik (maudhu'i). Penelitian ini menyimpulkan bahwa antara siswa dan guru memiliki hak dan kewajiban yang saling melengkapi dan merupakan satu kesatuan. Artinya, hak seorang siswa adalah kewajiban seorang guru dan kewajiban seorang siswa adalah hak seorang guru. Keduanya, antara guru dan siswa, memiliki hak dan kewajiban yang sama dalam rangka menaati perintah Allah SWT.
\end{abstract}

Kata Kunci: Hak dan kewajiban, guru, siswa, surat Luqman ayat 13-19

\section{Pendahuluan}

Di antara elemen yang harus ada dalam pendidikan adalah guru dan siswa. Keberadaan dan hubungan antara keduanya menjadi sebuah keharusan dalam proses pendidikan. Sebab, seorang pendidik tidak dapat disebut sebagai pendidik jika tidak ada peserta didik, begitu juga sebaliknya. Sehingga, dapat dikatakan bahwa sebuah proses pendidikan tidak akan mungkin berlangsung tanpa keduanya. 
Jika ditelusuri dalam Al-Qur'an, sejauh kajian yang dilakukan penulis, tidak ditemukan pembahasan secara terperinci tentang hal-hal yang berkaitan dengan pendidik dan peserta didik. Namun, bukan berarti Al-Qur'an tidak sempurna. Karena, sebagaimana yang telah dipahami, AlQur'an adalah sebuah kitab suci yang berbicara tentang segala sesuatu secara umum dan kemudian dijelaskan lebih terperinci dalam sunnah Nabi Muhammad SAW (Mudlofir, 2011).

Walaupun demikian, Al-Qur'an telah memberikan isyarat tentang hak, kewajiban dan hubungannya pendidik dan peserta didik melalui ayat-ayat yang termuat di dalamnya. Di antara ayatayat tersebut, menurut penulis, adalah ayat 13-19 dalam surat Luqman. Untuk itu, dalam artikel ini, penulis mencoba menganalisis dan mendeskripsikan ayat-ayat tersebut dan mengaitkannya dengan pendidikan, terutama berkenaan dengan hak dan kewajiban peserta guru dan siswa.

\section{Metode Penelitian}

Penelitian ini merupakan studi literatur atau kajian pustaka, sehingga metode yang digunakan dalam penelitian ini adalah metode analisis isi (content analysis) yaitu suatu analisis yang menekankan pada analisis tentang isi pesan suatu komunikasi (Lexy J. Moleong, 1990). Analisis isi memanfaatkan prosedur yang dapat menarik kesimpulan shahih dari sebuah buku atau dokumen (Muhajir, 1996). Di samping menggunakan metode analisis isi, penulis juga menggunakan metode tafsir tematik (maudhu'i) yaitu mencari makna yang sama dengan topik yang dibahas. Melalui metode tafsir tematik ini penulis memberikan penjelasan surat Luqman ayat 13-19 dengan ayat dan hadits terkait maupun pendapat beberapa pakar yang concern dalam bidangnya. Adapun dengan metode analisis isi, penulis mencoba memahami surat Luqman ayat 13-19 yang menjelaskan tentang hubungan orang tua dengan anak dikaitkan dengan hubungan antara guru dan siswa dalam hal hak dan kewajiban keduanya.

\section{Pengertian Guru (Pendidik)}

Sebelum penulis membahas tentang surat Luqman ayat 13-19, maka ada baiknya penulis di sini memaparkan terlebih dahulu definisi atau pengertian guru dan siswa dalam ruang lingkup pendidikan Islam, baik secara bahasa maupun secara istilah. Tujuan pemaparan ini adalah agar diketahui batasanbatasan serta cakupan yang jelas. Penyebutan guru dalam beberapa literatur memiliki beragam jenis istilah, dimana istilah-istilah tersebut memiliki perbedaan akan tetapi secara substansinya terdapat sisi kesamaan (Nanang \& Sifa, 2016). Di dalam Kamus Besar Bahasa Indonesia (2008), istilah guru merupakan kata benda yang mengandung makna orang yang pekerjaannya (mata pencahariannya atau profesinya) mengajar. Apabila diimbuhi awalan ke- dan diakhiri -an menjadi "keguruan," maka mengandung arti perihal pengajaran, pendidikan, metode (pengajaran dan lain sebagainya). Dalam bahasa Inggris, kata guru dikenal dengan istilah teacher, kata kerjanya adalah teach, taught, teaching yang memiliki arti; pertama, menunjukkan bagaimanan untuk melakukan (show how to do) dan memahamkan (make understand); kedua, memberikan pelajaran-pelajaran (give lessons); dan ketiga, berbuat sebagai guru (act as teacher). Jadi, seorang guru (teacher) adalah orang yang mengajar (person who teaches) (Barnhart, 2008). Adapun dalam literatur bahasa Arab, guru dikenal dengan beberapa istilah, yaitu mu'allim, mudarris, ustadz, murobbi, muaddib, mursyid, dan syaikh (Muhaimin, 2003). Dengan adanya beberapa istilah yang memiliki akar kata yang berbeda tersebut, ini tentunya akan berimplikasi pada perbedaan makna istilah yang terkandung di dalamnya.

Melalui beberapa istilah yang dijelaskan di atas dapat dipahami bahwa seluruh istilah tersebut memiliki konotasi yang sama dalam konteks pendidikan sesuai dengan peranan atau porsinya masing- 
masing. Untuk itu ada baiknya penulis memaparkan penjabaran dari istilah-istilah guru di atas sehingga akan diketahui peranannya masing-masing. Pertama, kata mu'allim berasal dari kata 'allama yu'allimu ta'liman yang berarti mengajar (Munawwir, 2010). Kata mu'allim adalah fa'il (subjek) yang bermakna bahwa seorang guru dituntut agar mampu menjelaskan hakikat sesuatu, baik secara teoritis maupun praktis. Kedua, kata mudarris berasal dari kata darrasa yudarrisu tadrisan yang berarti mengajar. Kata mudarris berarti pengajar atau guru (Wehr, 1979). Dari sini berarti seorang guru bertugas mencerdaskan siswa, menghilangkan atau menghapus kebodohan dan mengajarkan berbagai pengetahuan sehingga bakat dan potensi yang dimiliki para siswa dapat digali dan dikembangkan. Ketiga, kata ustadz dalam bahasa Arab biasanya digunakan untuk panggilan seorang professor di perguruan tinggi (Wehr, 1979). Hal ini memiliki arti bahwa seorang guru harus mengerti bidang yang digelutinya, memahami tugas dan fungsinya serta memiliki komitmen yang tinggi dalam melaksanakan kewajibannya. Keempat, kata murabbi berasal dari kata rabbaa yurabbi tarbiyyatan yang berarti mengasuh, mengelola dan memelihara (Mandzur, n.d.). Istilah ini merupakan fa'il (subjek) dari istilah yang sudah familier di dunia pendidikan Indonesia yaitu tarbiyyah. Guru sebagai murabbi artinya seorang guru dituntut untuk mampu memelihara, mengasuh dan menyiapkan siswa untuk dapat secara kreatif mengembangkan potensi yang telah dianugerahkan oleh Allah SWT kepada dirinya sehingga siswa dapat memelihara alam semesta yang merupakan ciptaan dari Allah SWT, Tuhan semesta alam (rabbul 'alamin). Kelima, kata muaddib berasal dari kata addaba yuaddibu ta'diban yang berarti mendidik (Wehr, 1979). Kata ini memiliki akar kata yang tidak jauh berbeda dengan adab dan peradaban. Guru sebagai muaddib berarti guru dituntut untuk mengembangkan aspek jasmani sekaligus rohani para peserta didiknya yaitu dengan mengedepankan aspek moral dan akhlaknya, sehingga akan menghasilkan para siswa yang beradab dan dapat membangun sebuah peradaban. Keenam, kata mursyid berasal dari kata arsyada yursyidu irsyadan yang berarti memimpin, membimbing dan menunjukkan (Munawwir, 2010). Biasanya istilah ini lebih masyhur dalam dunia tasawwuf atau thariqah. Guru sebagai mursyid dalam konteks pendidikan berarti guru dapat membimbing, mengarahkan dan memberikan petunjuk jalan ke dunia ilmu pengetahuan sehingga melahirkan siswa yang cerdas secara intelektual, emosional dan spiritual. Dan ketujuh, kata syaikh adalah bentuk mashdar dari kata syaakho yasyiikhu syaikhon yang berarti orang tua (Munawwir, 2010). Dalam Lisanul 'Arab dijelaskan bahwa seseorang disebut syaikh ketika usianya telah melebihi 50 tahun (Mandzur, n.d.). Di sini, guru menurut pengertian ini adalah sosok yang memiliki pengetahuan dan pengalaman yang luas dan matang.

Keseluruhan kata tersebut di atas tampak terhimpun dalam kata pendidik, sebab seluruh kata tersebut mengacu pada seseorang yang memberikan pengetahuan, pengalaman atau ketrampilan kepada orang lain (Khusnan Iskandar, 2017). Hanya saja, perbedaan penyebutan tersebut disesuaikan dengan ruang gerak dan lingkungan dimana ilmu dan pengetahuan diberikan. Dari sini dapat dipahami bahwa, kata guru secara fungsional tertuju kepada seseorang yang melakukan kegiatan dalam memberikan pendidikan, pengalaman dan sebagainya.

Dari beberapa pengertian di atas dapat disimpulkan bahwa seorang guru adalah sosok yang yang memiliki kompetensi keilmuan sesuai dengan bidang yang digelutinya. Guru tidak hanya menjadi pengajar, tetapi juga pendidik, pengarah, penilai, pelatih, serta pembimbing (Purnama, 2019) yang memiliki peranan penting dalam menggali dan menumbuh kembangkan potensi siswa dalam rangka mewujudkan generasi yang beradab dalam rangka membangun sebuah peradaban maju. 


\section{Pengertian Siswa (Peserta Didik)}

Secara bahasa, siswa dalam bahasa arab disebut dengan istilah thalib, jamaknya adalah thullab, yang artinya "mencari", maksudnya adalah "orang yang mencari ilmu" (Tirmidzi, 1998). Selain thalib, siswa dalam bahasa Arab juga dikenal dengan istilah al muta'allim yang artinya "orang yang belajar" (Zarnuji, 2004). Dalam bahasa arab juga dikenal dengan istilah tilmidz jamaknya adalah talamidz, yang artinya adalah "murid", maksudnya adalah "orangorang yang belajar ilmu pada seorang guru" (Jabbar, n.d.).

Adapun secara istilah, dalam pendidikan Islam, siswa diartikan sebagai orang yang belum dewasa dan memiliki sejumlah potensi dasar (fitrah) yang perlu dikembangkan (Suharto, 2011; Triwidyastuti, 2018). Siswa atau peserta didik juga diartikan sebagai komponen yang tidak dapat terlepas dari sistem pendidikan sehingga dapat dikatakan bahwa peserta didik merupakan obyek pendidikan. Siswa, diartikan sebagai "bahan mentah" dalam proses transformasi pada pendidikan, yang berarti bahwa peserta didik merupakan individu yang belum dewasa. Siswa atau peserta didik adalah anak kandung dalam sebuah keluarga, siswa adalah anak didik di sekolah, anak-anak penduduk adalah peserta didik masyarakat sekitarnya dan umat beragama menjadi peserta didiknya ruhaniawan dalam suatu agama (Mujib, 2006; Nizar, 2010).

Jadi secara umum dapat disimpulkan bahwa siswa dapat didefinisikan sebagai seseorang yang memiliki fitrah akan tetapi belum mencapai kedewasaan dan memerlukan orang lain untuk mendidiknya sehingga menjadi individu yang dewasa, memiliki kematangan dalam intelektual, emosional dan spiritual.

\section{Gambaran Umum Kandungan Surat Luqman Ayat 13-19}

Surat Luqman terdiri dari 34 ayat dan termasuk golongan surat-surat Makkiyyah. Surat ini diturunkan setelah surat Ash Shaaffaat. Dinamai Luqman karena pada ayat 12 disebutkan bahwa Luqman telah diberi oleh Allah nikmat dan ilmu pengetahuan. Oleh sebab itu, dia bersyukur kepada Allah atas ni'mat yang diberikan itu. Pada ayat 13-19 terdapat nasehat-nasehat Luqman kepada anaknya (Embun Bunyamin, 2015). Ini adalah isyarat dari Allah supaya setiap orang tua memerintahkan kepada anak-anak mereka sebagaimana perintah yang telah dilakukan oleh Luqman (Tim, 1971). Surat Luqman diambil dari seorang yang bernama lengkap Luqman bin Na'ur bin Nahur bin Tarikh. Dia adalah anak dari saudara perempuannya Ayub dan dia adalah seorang hakim (qadhi) Bani Israil (Baghawi, 1409).

Dalam Tafsir Ibnu Katsir, para ulama salaf berbeda pendapat tentang sosok Luqman, apakah dia seorang nabi atau seorang hamba yang shaleh. Tapi mayoritas mengatakan bahwa Luqman adalah seorang hamba yang shaleh dan bukan seorang nabi (Dimsyiqi, 2000). Hal ini juga dikatakan oleh al Baghawi dalam tafsirnya, bahwa para ulama sepakat jika Luqman adalah seorang ahli hikmah (orang yang bijak atau hakim) dan bukan seorang nabi (Baghawi, 1409). Untuk itu, dalam hal ini, penulis lebih sepakat dengan pendapat para ulama yang menyatakan bahwa Luqman bukanlah seorang nabi.

Pada bagian ini penulis akan memaparkan kandungan dari surat Luqman ayat 13-19 dengan mengambil beberapa pendapat ahli tafsir (mufassir). Hal ini dimaksudkan untuk memperjelas makna dan maksud ayat sehingga dapat diketahui nasehat Luqman kepada anaknya. Oleh karena itu, penulis mencoba memaparkannya ayat demi ayat. 


\section{Ayat 13}

Ayat ini menjelaskan tentang nasihat Luqman kepada anaknya yang dimulai dari peringatan terkait perbuatan syirik. Luqman menjelaskan kepada anaknya bahwa perbuatan syirik itu merupakan kezaliman yang besar (Hidayat, 2016). Bahkan menurut Ibnu Katsir, syirik bukan hanya kedzaliman yang besar, tapi bahkan merupakan kedzaliman terbesar ( ' $^{\prime} d z a m$ adz $d z u l m$ ) (Dimsyiqi, 2000). Terkait besarnya dosa syirik ini, Allah SWT juga mempertegas dengan firman-Nya dalam surat An Nisa ayat 48 yang artinya; "sesungguhnya Allah tidak akan mengampuni dosa syirik, dan Dia mengampuni segala dosa yang selain dari (syirik) itu, bagi siapa yang dikehendaki-Nya. Barangsiapa yang mempersekutukan Allah, maka sungguh ia telah berbuat dosa yang besar." Ayat ini mengabarkan tentang pelaku syirik yang tidak diampuni oleh Allah SWT. Maksudnya, jika seseorang meninggal dalam keadaan syirik (belum bertaubat) maka dosanya tidak diampuni karena perbuataan syirik adalah termasuk dosa besar. Dalam ayat yang lain, Allah SWT juga telah mengancam para pelaku syirik dengan neraka jahannam. Sebagaimana firman-Nya dalam surat Al Maidah ayat 72 yang artinya; "sesungguhnya orang yang mempersekutukan (sesuatu dengan) Allah, maka pasti Allah mengharamkan kepadanya surga, dan tempatnya ialah neraka, tidaklah ada bagi orang-orang zalim itu seorang penolongpun."

Menurut Imam adz Dzahabi dalam kitabnya al Kabair, ayat di atas menjelaskan tentang orang yang meninggal dalam keadaan syirik (menyekutukan Allah) maka tempat kembalinya adalah neraka secara qoth'i (qhot'an), berbeda halnya dengan orang yang beriman dan meninggal dalam keadaan beriman, maka dia masuk surga walaupun di adzab terlebih dahulu di neraka (Imam adz Dzahabi, 2003). Jadi, dalam ayat 13 ini, Luqman memberikan nasehat yang sangat penting kepada anaknya tentang perbuatan dosa yang paling besar. Yang mana dosa ini oleh Imam adz Dzahabi dalam kitabnya tersebut dimasukkan dalam urutan pertama. Hal ini menunjukkan bahwa syirik merupakan perbuatan dosa yang harus dihindari oleh seorang muslim.

\section{Ayat 14 dan ayat 15}

Dua ayat ini menjelaskan bahwa seorang anak diperintahkan untuk berbuat baik kepada kedua orang tuanya sebagai wujud rasa syukur atas kebaikan keduanya, terutama kepada ibunya. Hal ini sebagaimana yang dijelaskan oleh Ibnu Jarir ath Thabari dalam tafsirnya (Thabari, 2001). Karena seorang ibu telah mengandungnya sejak janin di dalam kandungan. Setiap bertambah usia dan besar janin, semakin bertambah lemahlah ibu dan semakin bertambah kesulitannya. Terlebih saat melahirkan, seorang ibu dengan susah payah mengeluarkan bayinya dari rahimnya. Setelah itu, ibu menyusui bayinya selama dua tahun (Imam adz Dzahabi, 2003).

Menurut Ibnu Jarir ath Thabari, seorang anak diwajibkan untuk selalu taat kepada kedua orang tuanya selama orang tua tersebut tidak memerintahkan dalam perbuatan dosa. Apabila ada diantara keduanya menyuruh untuk berbuat kesyirikan, maka seorang anak dilarang untuk menaatinya. Akan tetapi ia harus tetap berhubungan baik dengan keduanya ketika hidup di dunia (Thabari, 2001). Senada dengan ath Thabari, Ibnu Katsir juga menafsirkan, apabila orang tua berusaha agar seorang anak mengikuti agama mereka (kesyirikan), maka seorang anak dilarang untuk mengikutinya, akan tetapi ia harus tetap berhubungan baik (ma'ruf) dengan keduanya selama di dunia (Dimsyiqi, 2000). Dengan demikian, ayat ini telah memberi batasan 
yang jelas tentang kewajiban seorang anak untuk mematuhi perintah kedua orang tuanya dengan tetap mengedepankan perintah Allah SWT.

\section{Ayat 16}

Dalam ayat ini, Luqman kembali mengingatkan anaknya agar berhati-hati dalam melakukan amal perbuatan. Luqman mengajarkan kepada anaknya bahwa jika ada perbuatan, baik itu dosa ataupun maksiat, walaupun seberat dan sekecil biji sawi, dan berada di tempat yang tersembunyi, misalnya di dalam batu, di langit, atau di bumi, maka kelak Allah SWT akan mendatangkan balasannya ketika ditimbang pada hari kiamat (Dimsyiqi, 2000). Sebab, Allah SWT memiliki sifat maha halus dan maha tahu. Ilmu Allah SWT meliputi segala sesuatu, bagaimanapun kecilnya, sehingga seekor semut yang berjalan di malam dalam keadaan gelapgulita pun tidak akan luput dari pengetahuan-Nya. Para ahli bahasa memiliki perbedaan dalam memaknai huruf "ha" dan "alif" dalam kalimat "innaha" pada ayat tersebut di atas. Menurut para ulama ahli nahwu Bashrah, sebagaimana yang dikutip oleh Ibnu Jarir ath Thabari dalam tafsirnya, kalimat "innaha" merupakan bentuk sindiran (kinayah) tentang perbuatan maksiat dan dosa. Sehingga, jika diterapkan dalam kalimat, ayat ini berbunyi "Ya bunayya, inna al ma 'shiyyata in taku mitsqola habbatin min khardalin, aw al khathiah..." (Thabari, 2001).

Terlepas dari perbedaan tersebut, pada intinya, ayat tersebut mengandung makna tentang balasan sebuah amal perbuatan yang dilakukan oleh seorang hamba. Ayat ini juga diperkuat oleh Allah SWT dalam firman-Nya yang lain, yaitu surat Az Zalzalah ayat 7-8 yang artinya; "barangsiapa yang mengerjakan kebaikan seberat dzarrahpun, niscaya Dia akan melihat (balasan)nya. Dan Barangsiapa yang mengerjakan kejahatan sebesar dzarrahpun, niscaya Dia akan melihat (balasan) nya pula."

\section{Ayat 17}

Dalam ayat ke-17 ini, Luqman kembali menasehati anaknya tentang kewajiban kepada Allah SWT. Kewajiban yang dimaksud adalah mendirikan shalat, memerintahkan kebaikan dan mencegah kemungkaran (amar ma'ruf nahyi munkar) serta bersabar atas musibah yang menimpanya. Maksud mendirikan shalat menurut Ibnu Katsir adalah dengan memperhatikan batasan-batasannya (hududuha), fardhu-fardhunya (furudhuha) dan waktu-waktunya (auqotuha). Sedangkan maksud dari memerintahkan kebaikan dan mencegah kemungkaran (amar ma'ruf nahyi munkar) adalah memerintahkan orang lain untuk melakukan perkara yang baik dan mencegah perkara yang buruk sebatas kemampuan (bihasbi thaqatika wa juhdika). Sedangkan maksud dari bersabar atas musibah adalah bersabar atas kesulitan saat memerintahkan kebaikan dan mencegah kemungkaran (amar ma'ruf nahyi munkar) (Dimsyiqi, 2000).

Penafsiran yang sama juga disampaikan oleh ath Thabari dalam mengartikan mendirikan shalat. Hanya saja, ath Thabari lebih luas dalam menafsirkan perihal memerintahkan kebaikan dan mencegah kemungkaran (amar ma'ruf nahyi munkar). Menurutnya, amar ma'ruf adalah dengan memerintahkan manusia untuk menaati Allah dan mengikuti perintah-Nya, sedangkan nahyi munkar adalah mencegah manusia dari bermaksiat kepada Allah dan terjerumus ke dalam keharaman (Thabari, 2001).

Dengan demikian, ayat ini mengandung makna perintah Allah yang kaitannya dengan pengabdian langsung kepada-Nya (hablum minallah) berupa perintah mendirikan shalat, dan 
berkaitan dengan sesama manusia (hablum minannas) yang berupa perintah mengajak manusia kepada kebaikan dan mencegah kemungkaran serta perintah untuk bersabar saat mengamalkan keduanya.

\section{Ayat 18}

Dalam ayat ini, Luqman menasehati anaknya untuk menjauhi akhlak tercela, yaitu larangan berpaling dari manusia karena sombong dan menganggap rendah orang lain, serta larangan berjalan di muka bumi dengan sombong. Sebab, Allah SWT tidak menyukai orangorang yang sombong dan membanggakan diri. Menurut Ibnu 'Abbas, sebagaimana yang dikutip oleh ath Thabari, ayat ini menjelaskan tentang larangan perbuatan sombong (takabbur), larangan merendahkan hamba-hamba Allah (ihtiqor 'ibadillah) dan larangan memalingkan muka saat berbicara dengan manusia (al i'radh 'anhum biwajhika idza kallamuka) (Thabari, 2001). Hal senada juga dijelaskan oleh Ibnu Katsir dalam tafsirnya (Dimsyiqi, 2000). Sehingga, menurut penulis, ayat ini lebih menekankan seorang hamba untuk senantiasa menjaga akhlaknya saat bergaul dengan sesama manusia, terutama untuk menghindari sifat sombong. Karena sifat sombong, sebagaimana yang dikatakan oleh adz Dzahabi, merupakan sifat Iblis (Imam adz Dzahabi, 2003).

\section{Ayat 19}

Ayat ke 19 dalam surat Luqman ini menjelaskan untuk perintah berakhlak baik. Dalam ayat ini, Luqman menasehati anaknya untuk berakhlak mulia kepada manusia, yakni dengan cara sederhana dalam berjalan, tidak terlampau cepat dan terburu-buru, tidak juga terlampau lambat dan bermalas-malasan, kemudian melunakkan suara (saat berbicara), dan tidak berteriak-teriak tanpa ada perlu, karena seburuk-buruk suara adalah suara keledai (Thabari, 2001).

Berkenaan dengan ayat ke-18 dan ke-19 di atas, Ibnu Katsir membahasnya cukup panjang. Dalam pembahasannya tersebut, ia menjelaskan tentang pentingnya sifat rendah hati (tawadhu). Selain itu, ia juga menjelaskan tentang besarnya dosa sombong (takabur). Ia mengutip sebuah hadits tentang ancaman bagi orang yang sombong yang tidak akan masuk surge (Dimsyiqi, 2000).

Dari penjelasan tentang kandungan surat Luqman ayat 13-19 tersebut di atas, dapat diambil kesimpulan bahwa apa yang telah disampaikan Luqman kepada anaknya merupakan bentuk nasehat yang sangat berharga dari orang tua kepada anaknya. Nasehat-nasehat yang disampaikan Luqman bukan hanya untuk kebaikan anaknya di dunia akan tetapi juga di akhirat (Masrur, 2013). Dalam pembahasan selanjutnya, setelah memahami kandungan ayat-ayat di atas, penulis mencoba untuk mengkaitkannya ke dalam ranah pendidikan Islam yang mencakup hak dan kewajiban seorang siswa kepada guru, dan atau sebaliknya.

\section{QS Luqman Ayat 13-19 dalam Konteks Interpretasi Pendidikan Islam}

Nasehat Luqman dalam ayat 13-19 di atas, menurut penulis, merupakan nasehat yang mencakup dua hubungan sekaligus, baik hubungan secara vertikal (antara manusia dengan Allah SWT), maupun hubungan horizontal (antara manusia dengan manusia lainnya), sehingga nasehat tersebut sangat mungkin untuk diaplikasikan dalam dunia pendidikan Islam, yaitu kaitannya antara hak dan kewajiban seorang siswa dan guru. Secara tekstual, surat Luqman ayat 13-19 di atas menjelaskan tentang proses pendidikan yang dilakukan oleh orang tua kepada anaknya, yang mencakup hak dan 
kewajiban seorang anak kepada orang tuanya, dimana dalam ayat tersebut orang tua berposisi sebagai subjek dan anak sebagai objek.

Di sini penulis mencoba menghubungkan ayat tersebut dengan pendidikan Islam, yaitu dengan memposisikan guru sebagai subjek yang menggantikan orang tua, dan siswa sebagai objek yang menggantikan anak. Hal ini bukan berarti penulis menggantikan isi dan maksud ayat Al-Qur'an, akan tetapi lebih pada pengembangan makna dengan cara penafsiran ayat yang dikaitkan dengan pendidikan Islam. Dengan demikian, dalam pembahasan ini, penulis mencoba menafsirkan surat Luqman ayat 13-19 dalam kaitannya dengan hak dan kewajiban antara siswa dan guru sebagai berikut:

\section{Ayat 13: Larangan menyekutukan Allah SWT}

Menurut penulis, jika melihat ayat ini, hal pertama yang harus didapatkan oleh seorang siswa dari gurunya adalah pendidikan tentang mengesakan Allah (tauhid). Mengesakan Allah berarti menanamkan ketauhidan. Artinya, seorang guru menanamkan kalimat "La ilaha illallah" sejak awal kepada siswa, karena kalimat ini merupakan sebab seorang memasuki surga sebagaimana hadits nabi yang berbunyi:

$$
\text { من كان آخر كلامه لاإله إلااله دخل الجنة (حديث حسن أخرجه أبو داود والحاكم) }
$$

Artinya: Barang siapa yang akhir ucapannya "La Ilaha Illallah" maka dia masuk surga. (Suyuthi, 1997)

Penanaman tauhid ini juga sesuai dengan apa yang disampaikan oleh Hafidz bin Ahmad al Hakami, bahwa, kewajiban pertama yang harus dilakukan oleh seorang hamba kepada Allah SWT adalah mengetahui Dzat yang memiliki sifat pengasih (ar rahman) dengan mengesakan Allah (tauhid). Hal ini ia katakan dalam kitabnya:

$$
\text { أول واجب على العبيد معرفة الرحمن بالتوحيد }
$$

Artinya: Kewajiban pertama atas seorang hamba adalah mengetahui Dzat yang memiliki sifat pengasih (ar rahman) dengan mengesakan-Nya. (Hakami, 1995)

Menurutnya, tauhid terbagi ke dalam dua macam, yaitu pertama, tauhid yang didasari dengan ilmu, berita (dari Allah) dan keyakinan (at tauhid al i'lmi al khabari al i'tiqadi) yang mencakup penetapan terhadap sifat kesempurnaan Allah dengan tidak menyerupakan sesuatu apapun (at tasybih). Dan kedua, tauhid yang didasari pada tuntutan, tujuan dan kehendak (at tauhid at thalabi al qashdi al iradi) yang mencakup peribadahan yang ditujukan kepada Allah semata dengan tidak menyekutukannya (la syarika lahu). Lebih lanjut, menurutnya, seluruh al-Qur'an dari awal hingga akhir membahas kedua jenis tauhid ini (Hakami, 1995).

Dalam al-Qur'an, kaitannya dengan ibadah, tujuan dari penciptaan manusia tidak lain adalah untuk beribadah kepada Allah SWT. Hal ini sebagaimana yang difirmankan-Nya dalam surat Adz Dzariyat ayat 56 yang artinya: "dan aku tidak menciptakan jin dan manusia melainkan supaya mereka mengabdi kepada-Ku."

Sebagaimana yang dijelaskan oleh Hafidz bin Ahmad al Hakami di atas, beribadah berarti salah satu bentuk megesakan Allah SWT. Dalam artian, tidak menyembah selain Allah dan mengabdikan diri hanya kepada Allah SWT. Dengan demikian, menurut penulis, dalam 
pendidikan Islam, hal pertama yang harus diajarkan oleh seorang guru kepada siswanya adalah memberikan dasar-dasar tauhid sebagai pondasi awal sebelum mengajarkan ilmu-ilmu yang lain. Sehinggga, seorang siswa dalam Islam memiliki hak menerima pendidikan berupa tauhid dan hak tersebut menjadi kewajiban seorang guru.

Ayat 14: Hak seorang siswa untuk mendapatkan pendidikan dari guru dan berterima kasih atas jasa-jasa yang telah diberikan oleh guru

Dalam kaitannya dengan pendidikan Islam, ayat ini menjelaskan tentang kewajiban seorang siswa untuk berbuat baik kepada gurunya. Pendidikan yang dilakukan oleh guru kepada siswanya adalah sebuah perjuangan yang membutuhkan pengorbanan. Oleh karena itu, seorang guru berhak mendapatkan balasan kebaikan dari seorang siswa, paling tidak ucapan terima kasih dari siswanya sebagai bentuk rasa syukur. Dengan demikian, seorang siswa memiliki kewajiban yang harus diberikan kepada gurunya yaitu berbuat baik kepada gurunya. Menurut Syaikh Hasyim Asy’ari, seorang cendekiawan muslim Indonesia yang juga merupakan tokoh pendiri organisasi masyarakat dan keagamaan terbesar di Indonesia, Nahdlatul 'Ulama, dalam kitabnya Adab al 'Alim wal Muta'allim, beliau menjelaskan tentang kewajiban-kewajiban yang harus diberikan oleh murid kepada gurunya. Hal ini termuat dalam adab seorang murid terhadap guru sebagaimana yang telah dibahas oleh Syaikh Hasyim Asy'ari dalam kitabnya tersebut. Menurutnya, setidaknya ada 12 poin adab yang harus dimiliki oleh seorang murid kepada gurunya (Asy'ari, 1415). Selain itu, dalam kitab Ta'limul Muta'allim, seorang siswa juga memiliki kewajiban untuk mengagungkan ilmu dan ahli ilmu. Menurut Zarnuji, seorang pencari ilmu (siswa) tidak akan mendapatkan ilmu dan manfaat ilmu kecuali dengan mengagungkan ilmu dan ahli ilmu (guru) (Zarnuji, 2004).

Jadi, di samping mendapatkan hak pendidikan, seorang siswa juga memiliki kewajiban kepada gurunya. Di antara kewajiban tersebut adalah dengan berterima kasih kepada guru serta memenuhi hak-hak yang harus didapatkan oleh guru.

\section{Ayat 15: Batasan ketaatan seorang siswa terhadap guru}

Ayat ini, kaitannya dengan pendidikan Islam, menjelaskan tentang batasan-batasan ketaatan seorang siswa kepada guru. Walaupun seorang siswa memiliki kewajiban untuk menaati dan mematuhi perintah guru, akan tetapi seorang siswa juga harus memperhatikan perihal ketaatan tersebut. Artinya, seorang siswa menaati perintah gurunya dengan catatan bahwa perintah tersebut tidak bertentangan dengan apa yang telah diperintahkan atau dilarang oleh Allah SWT. Hal ini sesuai dengan hadits yang dimuat dalam al Jami' al Kabir karya Tirmidzi dalam bab "La Tha'ata Li Makhluq fi Ma'shiyat al Khaliq," yang intinya hadits tersebut menjelaskan tentang larangan menaati makhluk dalam hal kemaksiatan kepada Khaliq (Tirmidzi, 1998).

Oleh karena itu, menurut penulis, seorang siswa sebaiknya memperhatikan dengan cermat sebelum memilih seorang guru. Seorang siswa seharusnya memilih guru atau pendidik yang lebih dalam ilmunya (a'lam), memiliki kematangan emosional (aura') dan memiliki pengetahuan yang lebih luas (asan). Hal itu sesuai yang disarankan oleh Zarnuji agar para penuntut ilmu mencari guru atau pendidik yang memiliki tiga kualifikasi tersebut (Zarnuji, 2004). Di samping itu, tentunya guru harus memiliki pengetahuan yang dalam tentang agama sehingga tidak mengajarkan hal-hal yang bertentangan dengan syariat agama. 


\section{Ayat 16: Buah dari amal perbuatan}

Dalam ayat ini, Allah menjelaskan tentang balasan dari setiap amal perbuatan. Artinya, kaitannya dengan pendidikan Islam, seorang siswa akan mendapatkan balasan sebagaimana yang dia kerjakan. Balasan tersebut dapat berupa kebaikan maupun keburukan tergantung pada amal perbuatan yang dia kerjakan. Apabila seorang siswa dalam aktifitas pendidikannya memiliki niat untuk beribadah kepada Allah SWT, maka Allah SWT akan memberikan pahala. Tetapi sebaliknya, apabila ia salah dalam meniatkan aktifitas pendidikan tersebut, maka Allah juga akan memberikan balasan berupa siksa. Maka sudah seharusnya bagi seorang siswa memurnikan niat dalam aktifitas pendidikannya hanya kepada Allah SWT sehingga ia mendapatkan balasan berupa kemudahan dalam mendapatkan ilmu dan balasan berupa pahala mencari ilmu.

\section{Ayat 17: Kewajiban untuk mendirikan shalat, menyebarkan kebaikan, dan mencegah kemungkaran serta bersabar atasnya}

Menurut penulis, melalui ayat ini, kewajiban seorang guru dalam pendidikan Islam tidak hanya menyampaikan pelajaran. Akan tetapi lebih dari itu, yakni memerintahkan siswanya untuk mengabdi kepada Allah SWT. Di antara bentuk pengabdian tersebut adalah dengan senantiasa mendirikan shalat. Karena shalat adalah bentuk pengabdian langsung seorang hamba kepada Allah SWT. Dan dalam al-Qur'an, terdapat banyak ayat yang telah menjelaskan tentang kewajiban mendirikan shalat tersebut.

Sebagaimana yang telah dijelaskan dalam kandungan ayat ini, mendirikan shalat berarti memperhatikan batasan-batasannya (hududuha), fardhu-fardhunya (furudhuha) dan waktuwaktunya (auqotuha) (Dimsyiqi, 2000). Sehingga, dengan demikian, apabila seorang siswa mendirikan shalat, berarti ia juga telah menunaikan dua kewajiban sekaligus, yaitu menunaikan kewajiban menaati guru dan kewajiban menaati perintah Allah SWT.

Selain perintah untuk mendirikan shalat, seorang guru juga berkewajiban memerintahkan siswanya untuk mengamalkan dan menyebarkan ilmu yang telah diajarkan serta memiliki kesabaran di dalamnya. Hal ini berarti juga seorang siswa memiliki kewajiban untuk menyampaikan ilmu yang telah diajarkan oleh gurunya, yaitu dengan menyampaikannya kepada orang lain dengan cara amar ma'ruf nahyi munkar serta sabar di dalam hal tersebut.

Ayat ke 18 dan 19: Kewajiban untuk menjauhi kesombongan dan kewajiban memiliki sifat rendah hati (tawadhu)

Di antara kewajiban lain yang harus dilakukan oleh seorang siswa adalah dengan menjauhi akhlak tercela (madzmumah), dalam hal ini adalah sifat sombong, dan menghiasi diri dengan akhlak terpuji (mahmudah) dengan senantiasa memiliki sifat rendah hati (tawadhu). Sebagai makhluk sosial, tentunya seorang siswa tidak akan lepas dari pergaulan sesama manusia. Untuk itu sudah seharusnya seorang siswa setelah mendapatkan ilmu, tidak lantas bangga diri atau sombong dengan memalingkan muka saat bertemu dengan sesama manusia atau merendahkan orang lain karena menganggap dirinya orang berilmu. Justru harus sebaliknya, seorang siswa dengan ilmu yang telah didapatkannya harus memiliki sifat rendah hati (tawadhu). 


\section{Kesimpulan}

Dari penjelasan di atas, penulis menyimpulkan, bahwa seorang siswa memiliki hak untuk mendapatkan pendidikan terbaik dari pendidiknya (gurunya). Pendidikan terbaik tersebut merupakan salah satu bentuk kenikmatan dari Allah SWT kepada peserta didik yang harus disyukuri. Adapun kewajiban siswa, secara umum, menurut penulis, ada dua poin penting yang dapat diambil dari QS Luqman ayat 13-19 kaitannya dengan pendidikan, yaitu: pertama, berkaitan hubungannya dengan Allah (hablum minallah), yakni seorang siswa harus menghindari dosa syirik (menyukutukan Allah SWT) dan mendirikan shalat. Kedua, berkaitan hubungannya dengan manusia (hablum minannas), yakni seorang siswa diwajibkan untuk berbuat baik kepada gurunya, senantiasa mengikuti dan mengamalkan apa yang telah diajarkan gurunya (selama itu tidak bertentangan dengan agama), mengamalkan ilmu dengan mendakwahkannya (amar ma'ruf nahyi munkar), senantiasa bersabar, menjauhi sifat sombong dan senantiasa memiliki sifat rendah hati (tawadhu).

Dari penjelasan tersebut penulis mengibaratkan bahwa antara siswa dan guru memiliki hak dan kewajiban seperti mata uang, dimana setiap sisinya saling melengkapi dan merupakan satu kesatuan. Artinya, hak seorang siswa adalah kewajiban seorang guru dan kewajiban seorang siswa adalah hak seorang guru. Keduanya memiliki hak dan kewajiban yang sama dalam rangka menaati perintah Allah SWT sebagaimana yang terkandung dalam QS Luqman ayat 13-19. Berdasarkan kesimpulan ini maka perlu kiranya diadakan penelitian lebih lanjut terkait hak dan kewajiban guru dengan mengeksplorasi ayat-ayat lain dalam al-Qur'an sehingga muncul pandangan-pandangan baru yang dapat dijadikan sebagai acuan menghidupkan nilai-nilai Al-Qur'an dalam praktek pendidikan Islam di era sekarang.

\section{Daftar Pustaka}

Asy'ari, H. (1415). Adabu al 'Alim wal Muta'allim. Maktabah at Turats al Islami.

Baghawi, A. M. bin al H. bin M. al. (1409). Tafsir al Baghawi: Ma'alim at Tanzil. Dar Thayyibah.

Barnhart, C. A. (2008). Student's Dictionary of American English. Facts On File, Inc.

Dimsyiqi, I. K. ad. (2000). Tafsir al-Qur'an al 'Adzim. al Faruq al Haditsiyyah Li ath Thiba'ah wa an Nasyr.

Embun Bunyamin. (2015). Konsep Perlindungan Anak dalam Al-Qur'an dan Relevansinya dengan Pendidikan. 10(1), 1-30.

Hakami, H. bin A. al. (1995). Madarij al Qubul bisyarhi Sullami al wushul ila 'Ilmi al Ushul. Dar Ibnu al Qoyyim.

Hidayat, N. (2016). KONSEP PENDIDIKAN ISLAM MENURUT Q.S. LUQMAN AYAT 12-19. TA'ALLUM, 04(46), 359-370.

Imam adz Dzahabi. (2003). al Kabair (, cet. Ke-2, 2003), hlm. 90-91. Maktabah al Furqon.

Jabbar, U. A. (n.d.). Madarij Ta'lim al Lughah al 'Arabiyyah. Maktabah Muhammad Bin Ahmad Nabhan wa Auladuhu.

Kamus Besar Bahasa Indonesia (2008). Pusat Bahasa.

Khusnan Iskandar. (2017). Profesionalime Guru dalam Pendidikan Islam dan Gambaran Ideal Seorang Pendidik. JALIE: Journal of Applied Linguistics and Islamic Education, 01, 21-40.

Lexy J. Moleong. (1990). Metode Penelitian Kualitatif (Bandung). Remaja Rosda Karya. 
Hak dan Kewajiban Guru dan Siswa dalam QS Luqman Ayat 13-19

I Alex Nanang Agus Sifa

Mandzur, I. (n.d.). Lisanul 'Arab. Darul Ma'arif.

Masrur, I. (2013). Pendidikan Islam dalam Upaya Meningkatkan Spiritual Anak: Kajian Surat Luqman. Episteme, 8(2), 347-370.

Mudlofir, A. (2011). Tafsir Tarbawi sebagai Paradigma Qur'ani dalam Reformulasi Pendidikan Islam. Al-Tahrir, 11, 261-280.

Muhaimin. (2003). Wacana Pengembangan Pendidikan Islam. PSAPM.

Muhajir, N. (1996). Metodologi Penelitian Kualitatif. Rake Sarasin.

Mujib, A. (2006). Ilmu Pendidikan Islam. Kencana Prenada.

Munawwir, A. W. (2010). Kamus Al Munawwir. Pustaka Progressif.

Nanang, A., \& Sifa, A. (2016). Urgensi Kompetensi Guru Dalam Implementasi Pendidikan Integratif. 11(1), 74-75.

Nizar, R. dan S. (2010). Filsafat Pendidikan Islam: Telaah Sistem Pendidikan dan Pemikiran Para Tokohnya. Kalam Mulia.

Purnama, M. (2019). Implementasi Pendidikan Agama Islam yang Integratif (Antara Guru, Orang Tua, dan Masyarakat). QALAMUNA: Jurnal Pendidikan, Sosial, Dan Agama, 11(2), 141-156. https://doi.org/10.5281/zenodo.3559273

Suharto, T. (2011). Filsafat Pendidikan Islam. Ar-Ruz Media.

Suyuthi, J. 'Abdurrahma as. (1997). al Arba'una Haditsan: fi Qawa'idi min al Ahkam asy Syar'iyyah wa Fadhail al A'mal wa az Zuhdi. Dar al Manarah.

Thabari, I. J. ath. (2001). Jami' al Bayan 'an Ta'wil al-Qur'an , juz XVIII, 2001), hlm. 550-551. Dar Hijri.

Tim. (1971). Al-Qur'an dan Terjemahnya. Yayasan Penyelenggara Penterjemah/Penafsir Al-Qur'an.

Tirmidzi, A. 'Isa at. (1998). al Jami' al Kabir Li at Tirmidzi. Dar al Gharbi al Islami.

Triwidyastuti, M. S. (2018). The Concept of Islamic Education Development Based on The Theory of Fitrah. Indonesian Journal of Interdisciplinary Islamic Studies (IJIIS), 2(1), 31-52.

Wehr, H. (1979). A Dictinory Of Modern Written Arabic (: , ), hlm. Otto Harrassowitz.

Zarnuji, B. (2004). Ta'lim al Muta'allim: Thariq at Ta'allum. ad Dar as Sudaniyyah lil Kutub. 